\title{
MAIN FEATURES OF GEOMORPHOLOGY OF THE SUDETES RE-ASSESSED IN THE LIGHT OF DIGITAL ELEVATION MODEL
}

P. Migon : Main features of geomorphology of the Sudetes re-assessed in the light of digital elevation model. - Geografie-Sborník CGS, 113, 4, pp. 400-416 (2008). - The Sudetes as a geomorphological region are distinguished by complicated spatial pattern of high- and low-altitude terrains and variable mean slope gradients across the range. Several conceptual models have been proposed to account for this variability, emphasizing the significance of planation surfaces, intramontane basins, climate-controlled landform generations, or differential uplift and subsidence. An analysis of a digital elevation model and maps derived from the model have allowed for re-assessment of some of those hypotheses and concepts. It confirms that differential tectonics explains best the morphological layout of the Sudetes, but its effects are superimposed on a variety of rock - landform relationships. Neither the model emphasizing the occurrence of tiered levels of relict planation surfaces, nor one assuming the widespread existence of distinctive landforms of tropical morphogenesis find support in the light of region-wide DEM analysis. The general landform pattern of the western part of the Sudetes differs from the one in the eastern part, the difference being the abundance of intramontane basins in the former.

KEY WORDS: mountain geomorphology - DEM - geodynamics - the Sudetes.

\section{Introduction}

The Sudetes (Fig. 1) constitute the north-eastern rim of the Bohemian Massif and attain the highest elevation (1,603 $\mathrm{m}$ a.s.l.) within it, surpassing the other marginal mountain ranges of Krušné hory Mts. and Sumava Mts. by $150-350 \mathrm{~m}$. They are also distinguished by their internal differentiation into a number of separate geomorphological units, rising to contrasting altitudes and very much different from each other in terms of landform inventories and morphometric parameters of relief. For example, a highaltitude plateau of vast extent which typifies Krušné hory Mts. and continues uninterrupted for many kilometres along the main water divide is missing in the Sudetes. On the other hand, deep intramontane basins, often elongated or rhomboidal in outline, are a very specific feature of geomorphology of the Sudetes, which hardly has an equivalent in other mountain terrains of the Bohemian Massif. Differences in height between the basin floors and summit surfaces of the surrounding ranges not uncommonly approach $1000 \mathrm{~m}$, which almost equals the relative relief of the Sudetes as a whole, as related to the lowlands to the north and south of the mountains.

Numerous attempts have been made to explain this peculiar large-scale geomorphology and to decipher the long-term evolution of landscape of the Sudetes. Several conceptual models have been presented by Polish (Jahn 1953, 1980; Klimaszewski 1958; Walczak 1968) and Czech researchers 


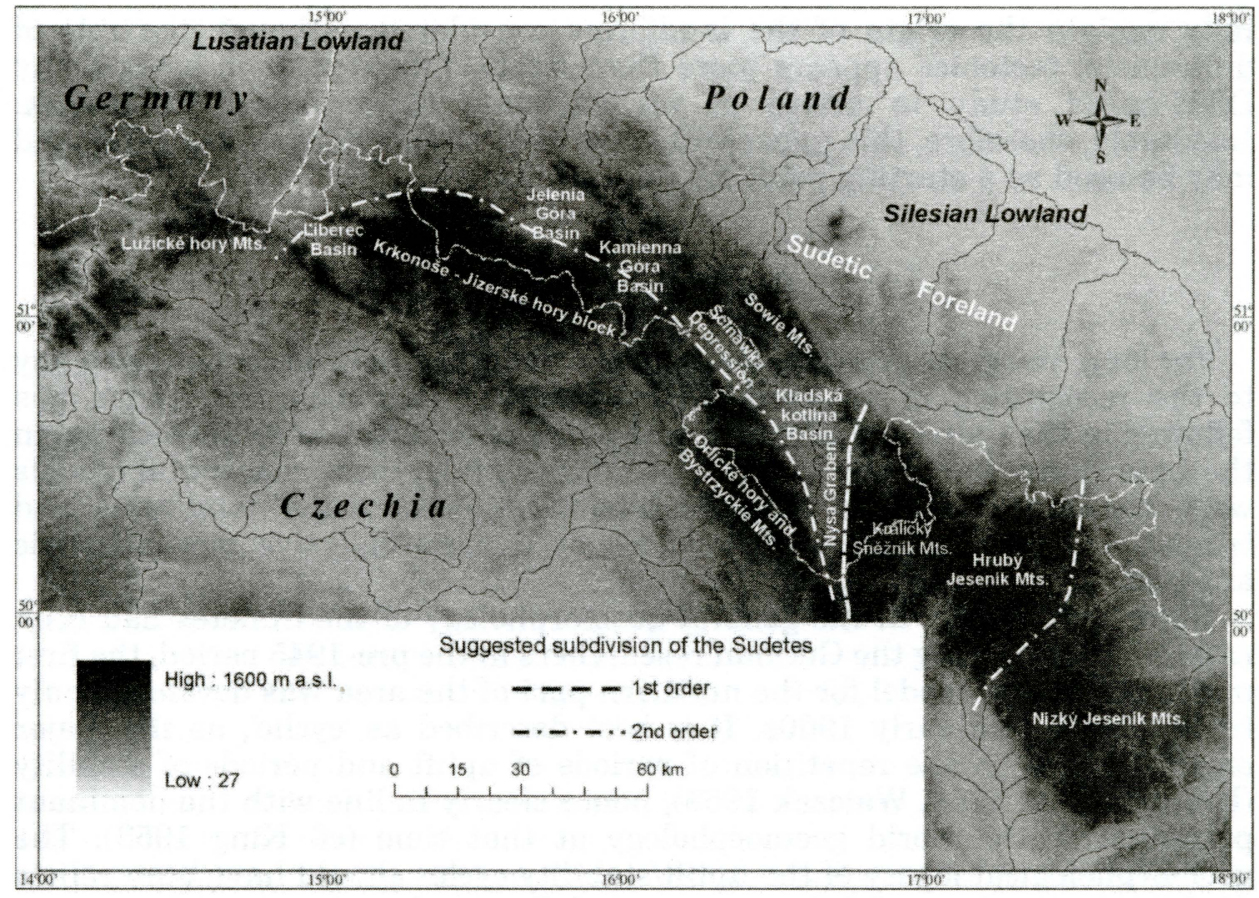

Fig. 1 - General hypsometry of the Sudetes, generated from the digital elevation model

(Czudek, Demek 1970; Kopecký 1972; Demek 1975, 1982), although the latter were devised for the Bohemian Massif as a whole, and these provided a framework adopted by subsequent workers in detailed studies in specific parts of the Sudetes. However, limited trans-boundary cooperation existed until the early 1990s and particular geomorphic models have been proposed using the evidence from either Polish or Czech side of the Sudetes, but hardly from both sides of the state border at the same time.

In the last 20 years or so an interest in gross geomorphology of the Sudetes diminished, as reflected in the decreasing number of publications addressing the issues of general geomorphology and the long-term landform evolution. Research efforts have been shifted to medium and minor landforms such as structural landforms or the geomorphic legacy of cold climate conditions, to small-scale indicators of neotectonics, or to detailed studies of late Quaternary history, chiefly of mountain glaciation. Perhaps the growing realization of insufficient database, subjectivity and over-reliance of the validity of initial assumptions have all contributed to this declining interest in region-wide geomorphology (see Migoń 1998). However, progress in research on Cainozoic deposits around the Sudetes and the advent of digital elevation models allows for the return to the 'classic' subject and for revisiting of certain concepts and models. This paper aims to offer a new look at the gross pattern of landforms within the Sudetes, using mainly the results of recent studies of a digital elevation model built for the entire Sudetes, across the state boundary. As a result of this exercise, a few well-embedded concepts of long-term landform evolution have been challenged. At the same time it needs to be emphasized that the approach presented here is insufficient to 
fully explain the origin of the landforms considered, although the role of differential tectonics appears more than likely. Likewise, it is beyond any DEM-based study to arrive at an adequate chronological framework. Inevitably, therefore, this paper will leave several questions unanswered and may be used as a starting point for future research.

\section{Previous concepts}

For long, the gross geomorphology of the Sudetes has been considered a key to the recognition of an evolutionary pathway this mountain range has followed in the Cainozoic, after the last phase of widespread sedimentation in the Late Cretaceous came to an end. Unfortunately, these conceptual models were based on a rather intuitive identification of major landforms and landscape facets, hardly supplemented by a more objective morphometric analysis.

Since the interest in the general geomorphology of the Sudetes had been rather limited among the German researchers in the pre-1945 period, the first major conceptual model for the northern part of the area was developed only in the 1950s and early 1960s. It is best described as 'cyclic', as the major emphasis was on the repetition of periods of uplift and periods of stability (Klimaszewski 1958, Walczak 1968), hence clearly in line with the dominant paradigm in the world geomorphology at that time (cf. King 1953). The geomorphological legacy of the uplift/stability cycles should have been relicts of planation surfaces of different ages at different altitudes. According to the model, a relict Palaeogene surface exists along the water divides, whereas younger, Miocene and Pliocene surfaces occur at lower altitudes. Indeed, tiered planation surfaces were claimed to be present in all geomorphic units in the Polish Sudetes. They were deemed to be the most important landscape facets of the Sudetes, which can be identified in each morphotectonic unit and correlated across the entire range.

A different approach was presented by Jahn (1980), who highlighted the role of changing climates throughout the Cainozoic and saw their legacy in the occurrence of a distinctive generation of palaeo-tropical landforms in the Sudetes. Although he continued to interpret the Sudetes in terms of progressive development of 'relief horizons' (= equivalents of planation surfaces from the earlier model, but evidently of higher relief), the emphasis shifted towards geomorphic features which were considered consistent with tropical relief of the present-day. Among them, intermontane basins acquired the major importance and were explained as products of concentrated deep weathering (etching) in initial topographic depressions. A notable comment was offered in this context: 'The Sudetic basins being the most important forms in the morphology of the mountains were formed in intertropical conditions. Their dependence on tectonics and lithology is indirect' (Jahn 1980: 21; italics from the present author). Step-like long profiles of rivers, tors and shield inselbergs, and sandstone plateaux would have been further geomorphic features inherited from Palaeogene to Miocene times and contemporaneous tropical and subtropical climates. Likewise, Czudek (1977) related to the concept of relief generations as advocated by J. Büdel and interpreted the watershed plains of Nízký Jeseník Mts. as mid-Cainozoic basal surfaces of weathering (etchsurfaces), inherited from warm and humid morphoclimatic conditions. 
Rather surprisingly, neither the proponents of the cyclic model of the 1950 s and 1960s nor Jahn later, attempted to decipher the morphotectonic structure of the Sudetes. Differential tectonics in the Tertiary was invoked by Klimaszewski (1958) and Walczak (1968), but no details were given and its spatial pattern remained unclear. This apparent neglect of endogenic factors stayed at odds with the parallel approach to the geomorphology of the Sudetes among the Czech researchers. Kopecký (1972) and then Demek (1975) strongly emphasized unequal uplift of the Sudetes towards the end of the Tertiary and correlated the most elevated mountain ranges with the most uplifted blocks. The view of Kopecký $(1972,1986)$, who argued for fold-like deformation of the Palaeogene surface and its survival almost intact, was heavily criticised (Ivan 1990) and largely abandoned. However, the concept by Demek (1975), in which fragmentation of the Sudetes into separate blocks, up- and down-faulted, is a key ingredient, has been adopted as a general framework to analyse the geomorphology of the Sudetes, although 'megafolding' is not completely ruled out, particularly with regard to the southern foreland of the mountains (Demek 2004).

Somewhat parallel, an inquiry into the nature of the early Tertiary to Miocene surfaces followed. In their seminal paper, Czudek and Demek (1970) demolished the idea of 'peneplain' survival in the Bohemian Massif, including the Sudetes, arguing for the existence of an etchplain instead. Relicts of a surface moulded by deep weathering in the Tertiary and subsequent stripping have been described from the rolling to hilly terrain of Nízký Jeseník Mts. (Czudek 1977, 1995), the granite inselberg area around Žulova in the Sudetic Foreland (Demek 1976), numerous parts of the Sudetic Foreland in Poland (Migon 1997), and their more problematic counterparts from the more elevated massifs, including the summit parts of Krkonoše Mts. (see Migoń, Pilous 2007).

Back to the geomorphic research in Poland, studies carried out in the 1990s largely disassociated from the former views and interpreted several individual mountain massifs as block-faulted terrain units, broken into arrays of tectonic steps and half-grabens (Migon 1991; Krzyszkowski, Pijet 1993; Migoń, Potocki 1996; Sroka 1997). A similar line of inquiry was followed by Ivan $(1997,1999)$. Results of morphotectonic analysis from these different massifs, taken together, have strongly suggested that the Sudetes are indeed a horst-and-graben type of relief, thus confirming the rather general view by Demek (1975), but remained to be integrated range-wide.

The very last developments concern the re-assessment of the role of lithology and variable rock resistance as factors contributing to the geomorphological diversity of the Sudetes. An independent evaluation of rock resistance, based on measurements of rock strength of representative rock complexes, indicates clearly that many facets of the present-day geomorphic landscape of the Sudetes may be satisfactorily explained by rock resistance contrasts but these seem to be subordinate to the more general relief pattern (Placek, Migoń 2007, Placek 2007).

\section{Digital Elevation Model}

Geomorphometric studies have long been considered as an important component of geomorphology, its main advantage being the ability to show landforms more objectively, via different primary and derived morphometric 
characteristics, and to pursue comparative analysis. Digital Elevation Models (DEM) are now standard tools in geomorphological research but their use in the Sudetes has been limited so far. One of the early examples was the geomorphological analysis of Lužické hory Mts. by Chvátalová (2000). Badura and Przybylski (2005) analysed shaded 3-D relief models of the Sudetes derived from a 1:50,000 DEM and highlighted several intriguing features of highly problematic origin, including possible meteoritic impacts (Przybylski, Badura 2004). In another study, the 3-D images assisted the morphotectonic analysis of the mountain front related to the Sudetic Marginal (Boundary) Fault (Badura et al. 2003), and later to delimit triangular facets along the mountain front (Badura et al. 2007). Likewise, Wojewoda (2007) employed DEM analysis in the morphotectonic studies of the central part of the Middle Sudetes. However, until recently DEMs have not been used to analyse the Sudetes as a whole, except for a recently published study of the distribution of low-gradient surfaces (Placek et al. 2007). This is in contrast to the wide use of DEMs in geomorphological studies elsewhere, where they proved extremely helpful in highlighting landscape features previously unaccounted for (e.g. Kuhlemann et al. 2005, Miliaresis 2006) or in supporting comparable quantitative analysis of large-scale landforms (e.g. Matmon et al. 2002).

Re-assessment of the large-scale morphology of the Sudetes offered in this paper is based on a DEM purposefully created in the Department of Geography and Regional Development, University of Wrocław ${ }^{1}$. The scale and spatial resolution were dictated by the aims of the study and the intention to identify landform patterns which would be significant regionally rather than locally. For the Polish side of the Sudetes, the DEM has been generated using the ArcMap software, from analogue topographic maps in 1:25,000 scale using manual vectorization method. The contour lines, with $25 \mathrm{~m}$ spacing, important elevation points and all drainage lines have been digitized. Subsequently, vectors were interpolated by the Topo-to-Raster tool to create a $50 \mathrm{~m}$ resolution raster. Then, the model has been supplemented for the Czech and German side by data from the DTED (Digital Terrain Elevation Data), available in $30 \mathrm{~m}$ resolution. The resolution and geographic coordinate system have been standardized and both models have been merged. The $50 \mathrm{~m}$ resolution and $25 \mathrm{~m}$ contour line have been chosen as sufficient and appropriate for further analysis at a regional scale. Gradient maps have been derived automatically, using the Spatial Analyst procedure (Surface Analysis tool in ArcGIS).

\section{Main features of relief}

Although geographical and geomorphological regionalization traditionally divides the Sudetes into a great number of smaller units and subunits (Czudek et al. 1972; Gilewska 1991; Kondracki 1994; Balatka, Kalvoda 2006), the regional DEM suggests a basic, bipartite division of the north-eastern rim of the Bohemian Massif. The western part includes an area from the Labe River in the west, through Lužické hory Mts., Krkonoše - Jizerské hory block

1 DEM for the Sudetes was prepared by Wiesława Żyszkowska and Agnieszka Placek, within a project "Main features of geomorphology of the Sudetes in the light of geomorphometry and rock resistance, using GIS", coordinated by the present author and supported by the Ministry of Science and Higher Education through a research grant no.

3 P04E 02123. 
into the middle part of the range, as far as the mountain front separating the Nysa Graben and Králický Sněžník Mts. (Fig. 1). The eastern part includes the Králický Sněžník Mts., Hrubý Jeseník Mts., and continues to the Moravská brána Gate. The main differences between these two major units are the general style of relief and the percentage of low-altitude terrain within and around the most elevated blocks.

The West Sudetes (in the sense of the subdivision introduced above) are composed of a number of isolated elevated massifs of different size, separated by basins and intramontane troughs. The Krkonoše - Jizerské hory Massif and the massif of Orlické hory Mts. - Bystrzyckie Mts. stand out as the largest, compact blocks of roughly rectangular shape (Fig. 1). Evident mountain fronts provide geomorphic boundaries to these units, particularly on the northern side of the former and the eastern side of the latter. Across these lines, altitudes decrease from $900-1,100 \mathrm{~m}$ a.s.l. to as low as $350-450 \mathrm{~m}$ a.s.l. The respective southern and western boundaries of these two massifs are less clear, but associated with long stretches of deeply incised valleys, largely absent on the opposite sides. Several other massifs in the West Sudetes rise to $900-1,000 \mathrm{~m}$ a.s.l., but their spatial extent is much smaller and the outline less regular. A very specific and unique type of geomorphology is presented by the Lužické hory Mts. in the extreme west. Here, the relief is dominated by isolated hills and their clusters rising above the surroundings by as much as $300-400 \mathrm{~m}$.

In between the elevated massifs numerous basins of different size occur. The largest of them is located in the eastern part of the unit. Traditionally, Kladská kotlina Basin, the Nysa Graben, and the Ścinawka Depression are distinguished here, but the relief map shows that they merge into one major topographic depression of triangular shape, pointing towards NE. In the western direction, more basins can be identified, including the distinctive rhomboidal Jelenia Góra Basin and the triangular Liberec Basin. However, other basins, such as the low-lying terrain around Kamienna Góra, are highly irregular in outline. Finally, the West Sudetes distinguish themselves by a wide belt of marginal uplands at $300-500 \mathrm{~m}$ a.s.l., particularly in the NW part. It is only the NE part where, along the mountain front related to the Sudetic Marginal Fault, the mountainous terrain of the Sowie Mts. falls down steeply to the Sudetic Foreland. In the remaining area the very location of the boundary of the Sudetes as geomorphological unit is problematic and somewhat arbitrary.

The geomorphological style of the East Sudetes (again, in the sense of the above subdivision) is very much different. Intramontane basins, which are so abundant in the west, largely disappear and those very few which exist (e.g. triangular basin around the town of Jeseník) are less distinctive. Consequently, the elevated terrain is much more close together and the passes separating individual massifs are located above $700 \mathrm{~m}$ a.s.l. At the same time, all these massifs are considerably dissected, with individual valleys reaching far into the cores of the mountains (e.g. in Králický Sněžník Mts. and along the eastern side of Hrubý Jeseník Mts.). Major topographic boundaries appear to strike $\mathrm{N}-\mathrm{S}$ to $\mathrm{NNE}-\mathrm{SSW}$ and delimit rectangular blocks.

Nízký Jeseník Mts. represents a geomorphological landscape in its own, without parallels elsewhere in the Sudetes. It is typified by an extensive, gently rolling plateau rising to $600-800 \mathrm{~m}$ a.s.l. Fluvial dissection does occur and clearly proceeds from the topographic margins of the area inward, but so 


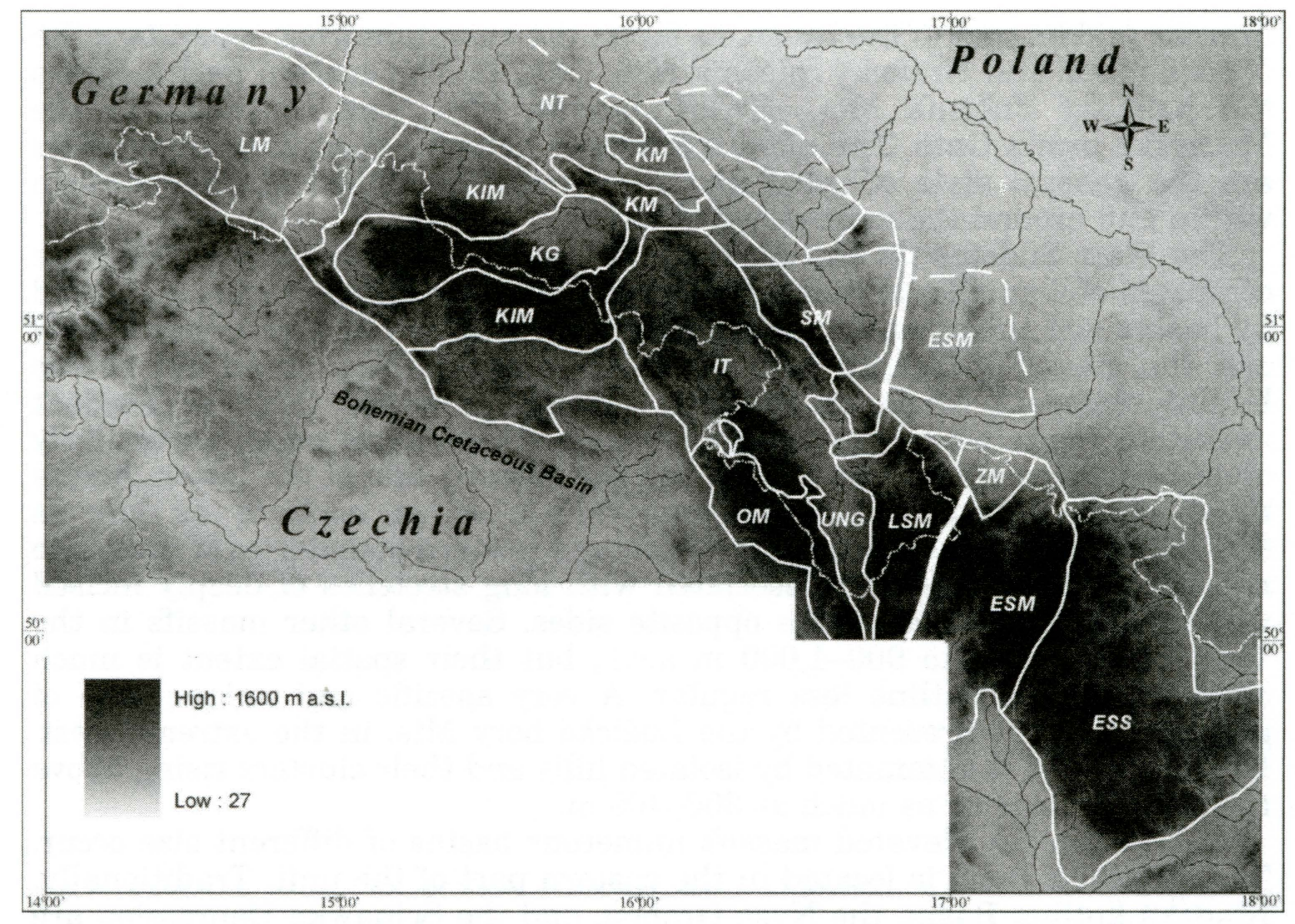

Fig. 2 - Main geological boundaries within the Sudetes superimposed onto the digital elevation model. The thick line indicates the boundary between the West Sudetic and East Sudetic terranes (after Żelaźniewicz 2005), broken lines mean an onlapping cover of Cainozoic sediments. Only major geological units are explained. LM - Lausitz Massif, KIM - Karkonosze-Izera Metamorphic Massif, KG - Karkonosze-Izera Granite Massif, NT North-Sudetic Trough, KM - Kaczawa Metamorphic Unit, IT - Intra-Sudetic Trough, SM - Sowie Mts. Massif, OM - Orlica Metamorphic Unit, UNG - Upper Nysa Graben, LSM Lądek-Śnieżnik Metamorphic Units, ESS - East Sudetic sedimentary Fold-and-thrust Belt.

far it failed to transform the plateau into a ridge-and-valley topography. Another feature of the East Sudetes is the rather limited extent of lowaltitude ( $<400 \mathrm{~m}$ a.s.l.) uplands and foothills.

Interestingly, the above subdivision into two major units mirrors the general geological subdivision of the Sudetes, although the boundary between the two compartments is not identical (Fig. 2). The geological boundary between the West and East Sudetes, made by the Staré Město Zone, is located more to the east (Żelaźniewicz 2005) and goes through the mountainous terrain. Several SSW-NNE trending valleys roughly follow this structural line, but overall this important geological boundary is poorly revealed in the regional morphology and crosses water divides in many sections. Likewise, the prolongation of this zone in the northern foreland of the Sudetes does not correspond with any general change in morphology.

In addition to the division of the Sudetes as presented above, the existence of further morphological entities of lower order may be inferred from the relief and altitude map (Fig. 1). The West Sudetes appear to have a higher, inner part and a lower, outer part, facing the Silesian and Lusatian Lowland. Within the former, the proportion of high-altitude terrain is much higher, whereas in the latter it is only the Sowie Mts. where elevation exceeds 1,000 m a.s.l., and 


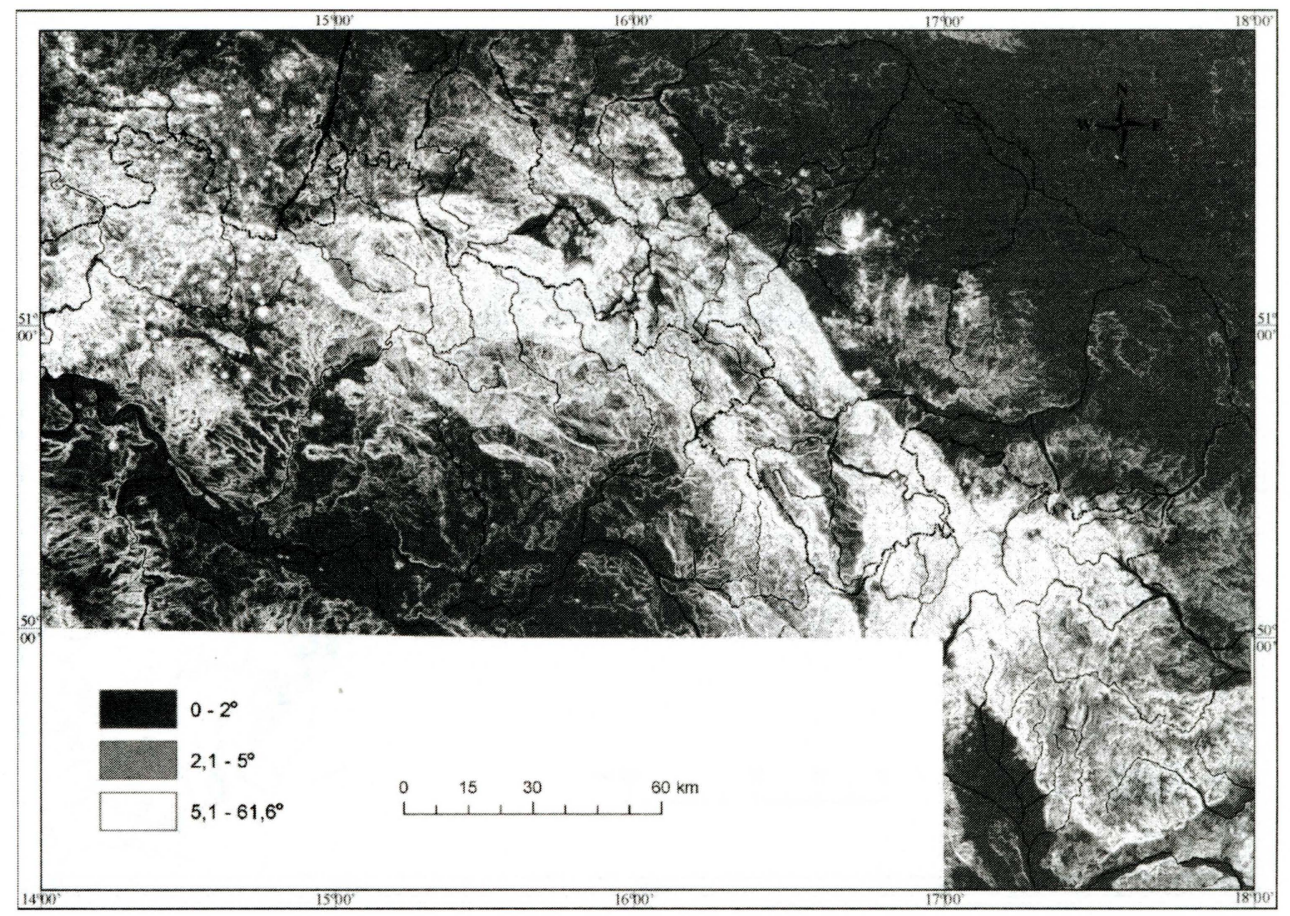

Fig. 3 - Spatial distribution of low-gradient slopes in the Sudetes and their surroundings. Mean slope angle calculated for $50 \times 50 \mathrm{~m}$ squares.

even this only by $15 \mathrm{~m}$. The dividing line may be traced along the western shoulder of the Nysa Graben, north-eastern scarp of the Cretaceous sandstone plateau (Stolové hory Hill country and Broumovské stěny Hill country), into the Kamienna Góra Basin, along the northern margin of the Krkonoše Jizerské hory Massif and towards the western tip of Ještěd. Most of large intramontane troughs and depressions occur east and north of this line.

The East Sudetes in turn can be further subdivided into a major high in the north-west and an extensive low in the south-east. The boundary between the two runs roughly SW-NE, along the eastern footslope of Hrubý Jeseník Mts. and Zlatohorská vrchovina Hill country.

\section{High-gradient and low-gradient areas}

The potential of slope gradient maps in geomorphology is manifold. In the context of the large-scale geomorphology of the Sudetes, they have been used mainly to delimit objectively the extent of landforms which have been claimed highly significant for the entire area: planation surfaces and fault-generated escarpments.

The problem of the so-called planation surfaces in the Sudetes has been discussed at length elsewhere (Placek et al. 2007). Hence, only a summary of the main findings is presented here. Perhaps the most important observation derived from a partial map of slope gradients within the range $0-5^{\circ}$ (Fig. 3) is the very limited extent of low-gradient surfaces at high elevation. Their 


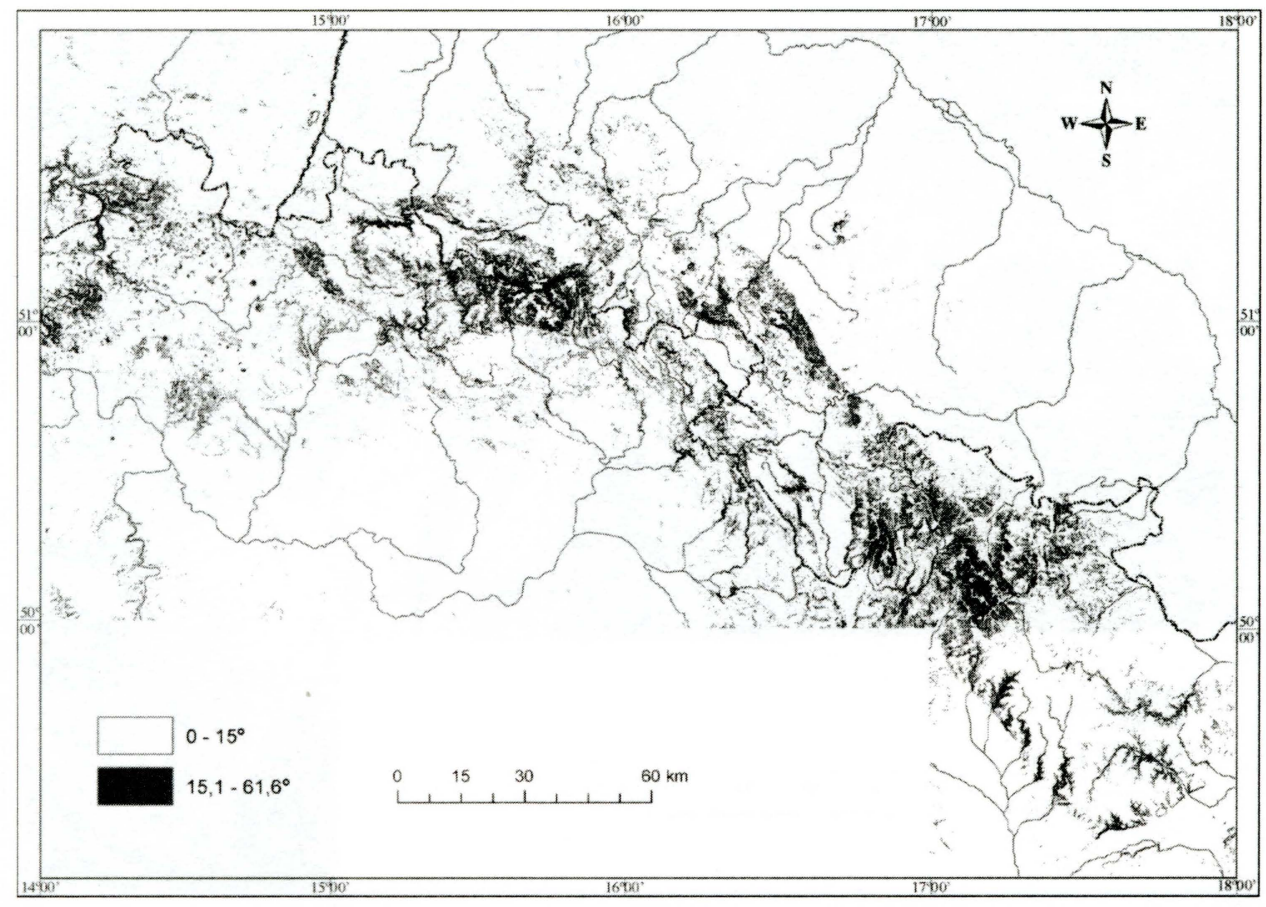

Fig. 4 - Spatial distribution of high-gradient slopes in the Sudetes and their surroundings. Mean slope angle calculated for $50 \times 50 \mathrm{~m}$ squares.

absence is particularly pronounced in the most elevated part of the East Sudetes, from Králický Sněžník Mts. in the west to the Hrubý Jeseník Mts. In the West Sudetes the extent of $0-2^{\circ}$ surfaces within the high altitude terrain is also small, but if the $0-5^{\circ}$ is considered, then certain areas begin to show up. These include the Jizerské hory Mts., Stolové hory Hill country and, especially, Bystrzyckie Mts. Rather surprisingly, at the resolution of the DEM used, the visually impressive summit plains of Krkonoše Mts. almost fail to be revealed.

By contrast, low-gradient surfaces appear distinctively at low elevations, within intramontane basins, along some of the major rivers, and across marginal uplands. Altogether, they occupy c. 15 per cent of the Sudetes. The most extensive area of their occurrence is in the north-west. However, this is also the least elevated part of the Sudetes, with indistinct northern boundary, which has been the area of net deposition rather than erosion since the Miocene. Therefore, much of the observed flatness of the terrain is due to deposition of fluvial, lacustrine, glacial and outwash sediments, and less because of long-term denudation of the solid rock. Further areas with widespread occurrence of low-gradient watershed surfaces are the transitional uplands between the Krkonoše - Jizerské hory Massif and the Bohemian Cretaceous Basin, although these level terrain units are separated by deeply incised valleys of various tributaries of Jizera, Labe, Upa and Orlice, and the upland of Nízký Jeseník Mts. The latter constitutes the most extensive area of low gradient in watershed position in the entire Sudetes.

Steep slopes $\left(>15^{\circ}\right)$ occur in different parts of the Sudetes, but with varying abundance (Fig. 4). To some extent, the $>15^{\circ}$ gradient map is a negative image 
of the $0-5^{\circ}$ map, in the sense that the Krkonoše Mts. and the area from Králický Sněžník Mts. in the west to the Hrubý Jeseník Mts. in the east are revealed as belonging mostly to this class of slope gradient. Hence, in the Sudetes the highest altitudes coincide with the steepest average gradients. A few smaller areas scattered across the Sudetes show up in a similar way (e.g. Ještědský hřbet Ridge, Kamienne Mts. and Sowie Mts.).

Another distinctive spatial pattern of steep slopes is that of rather narrow elongated zones, which in some instances can be traced over tens of kilometres. These indicate two different landscape elements. Some are sinuous escarpments supported by gently dipping sedimentary rocks and are best seen in the central part of the Sudetes. Others are associated with plateau margins and are steep segments connecting the plateaux with the floors of intramontane basins. The northern margin of Jizerské hory Mts. and the western boundary of the Nysa Graben provide instructive examples. Interestingly, the north-eastern mountain front associated with the Sudetic Marginal Fault is not as evident on the gradient map as might be expected. In particular, the visibility of its north-western sector is very poor, indicating a much subdued escarpment and hence, probably little ongoing uplift. This, however, stands in contrast to the very low sinuosity (Krzyszkowski et al. 1995; Badura et al. 2003, 2007), typically taken as a proxy of very active tectonics along the mountain front (Bull, McFadden 1977).

Yet another setting in which considerable gradients occur is along fluvial valleys incised into the plateaux or sloping surfaces. These are most evident in the Czech part of the Sudetes, chiefly along the foot of Orlické hory Mts. and inward from the mountain fronts of the Nízký Jeseník Mts. Steep valley sides may line the valley floors by as long as $15-20 \mathrm{~km}$.

\section{Tectonic, lithologic and climatic influences: discussion based on DEM analysis}

The present-day morphology of the Sudetes is a transient product of protracted geomorphological evolution, the onset of which is usually placed at the Cretaceous/Palaeogene boundary and related to the ultimate withdrawal of the Cretaceous sea (Klimaszewski 1958, Walczak 1968, Demek 1975, Jahn 1980). During the ensuing 65 or so million years the area experienced changes in stress field and tectonic regime, as well as multiple changes of climatic conditions, from warm and humid to very cold in the Pleistocene. Hence, the contemporary landform pattern is assumed to reflect tectonic, lihologic and climatic influences. This general assumption has never been challenged, but there have been widely divergent opinions expressed as to which controlling factors have been dominant and which have been rather subordinate.

The analysis of gross topography of the Sudetes strongly suggests that the prime control on the landform pattern is tectonic. Several points can be made here. First, the regional pattern of high altitude and low altitude areas is poorly correlated with lithological boundaries and variable rock resistance, although exceptions do exist (Placek et al. 2007). The most notable one is the presence of the residual volcanic range of the Kamienne Mts. in the central part of the Sudetes which creates local relief up to $400-500 \mathrm{~m}$ in the apparent absence of differential uplift and subsidence. On the other hand, the Krkonoše - Jizera a granite massif is divided into a low altitude area in the north-east 
and an elevated plateau in the south-west, with the relative relief well in excess of $500 \mathrm{~m}$. Second, there is a correlation between altitude and the degree of dissection, which is consistent with a general rule that more uplift (in terms of both amplitude and rate) enhances erosion, which, followed by mass movement, leads to the steady-state mountainous landscape with little previous topography preserved (e.g. Adams 1985). All areas in the Sudetes rising above $1,200 \mathrm{~m}$ a.s.l. may be interpreted in this way. The best preserved planation surfaces in the mountain-top setting are associated with less elevation, from 600-800 m a.s.l. (Nízký Jeseník Mts.) to $1,000 \mathrm{~m}$ a.s.l. (Jizerské hory Mts., Bystrzyckie Mts.). Third, in the spatial distribution pattern of steep slopes large rectangular or rhomboidal structures are seen, which strengthens their interpretation as uplifted blocks delimited by fault zones. DEM analysis gives little support to the 'cyclic' concept of relief development of the Sudetes which relied on the alleged step-like occurrence of planation surfaces at different elevations.

Referring to the division of the Sudetes into the eastern and western part, introduced earlier in this paper, again tectonics is suspected to be the factor behind it. However, why grabens and other subsidence basins are fairly abundant in the West Sudetes and so scarce in the East Sudetes cannot be answered satisfactorily here. One possible reason is the decreasing strength of the lithosphere in the West Sudetes, related to regional variations in the heat flow. In the west it is by c. $20 \mathrm{~mW} / \mathrm{m}^{2}$ higher than in the eastern part of the Sudetes (Jarosiński, pers.comm.). Lithology may be an additional factor and several basins in the West Sudetes, particularly the smaller ones, have formed in weaker bedrock (Placek et al. 2007). Likewise, considerable lithological contrasts between adjacent geological units may bear on the mechanical heterogeneity of the area, which has been revealed in the 'neotectonic' period. The elevated and only marginally dissected terrain of Nízký Jeseník Mts. is puzzling, given its predominant lithology which is rather weak slate. No parallel landscape exists elsewhere in the Sudetes. Its relatively high altitude may be related to the forebulge position in respect to the Carpathians, although it is hardly consistent with the magnitude of lithospheric flexure actually decreasing westwards. On the other hand, as a lithologically homogeneous unit (broadly speaking) this crustal block may have been less prone to localized differential uplift and subsidence.

It remains an open question whether the observed topographic pattern does have any cause-and-effect relationship to the pre-Variscan and Variscan tectonic history, and to the terrane distribution in the Sudetes, as argued for Demek (2004). One problem here is that terrane boundaries, particularly in the West Sudetes, are poorly agreed (Aleksandrowski 2003, Żelaźniewicz 2005) and hence, difficult to correlate with morphology. In addition, the patterns of post-Variscan (late Carboniferous - Cretaceous) sedimentation and tectonic history in the intramontane troughs of the Sudetes apparently disregard the supposed terrane boundaries. Consequently, it remains unclear why should they not have been active in the late Palaeozoic and active again in the late Cainozoic. Thus, the influence of the very ancient tectonic features is, at best, indirect and secondary.

Lithology and local structure play an important, but rather subordinate part, accounting for second-order geomorphic features such as volcanic residual hills, inselbergs in the Sudetic Foreland, cuesta escarpments and numerous river gorges (Placek, Migon 2007). It is also worth noting that the most elevated parts of the Sudetes are mainly supported by rocks which are 
mechanically strong. It is thus probable that higher rock strength is crucial in sustaining high relief and delaying erosional dissection, particularly in the granite area of Jizerské hory Mts.

The presence of climate-controlled relief generations is difficult to confirm or reject through an analysis of DEM alone. However, if the strong case for the role of differential tectonics is taken into account (also Sroka 1997; Badura et al. 2007), coupled with the results of other studies emphasizing the role of variable rock resistance at the medium scale (Placek, Migon 2007), then the relevance of the climatic geomorphology framework to explain the present-day geomorphology of the Sudetes becomes highly dubious. The consequence of the scarcity of pre-Quaternary weathering residuals and deposits in the Sudetes and the uncertainties associated with dating of those which occur (Jahn et al. 2000), is our highly limited ability to verify and/or falsify the hypotheses of tropical inheritance.

The former emphasis on intramontane basins due to tropical deep weathering and their alleged NW-SE alignment to form the morphological axis of the Sudetes (Jahn 1980) is justified only for the West Sudetes. In the East Sudetes, no comparative features exist and the presence of inherited, palaeo-tropical landforms is uncertain ${ }^{2}$. In addition, the basins likely have more than one origin. The floor of the Jelenia Góra Basin has indeed formed with a substantial contribution from deep weathering (also Migon 1992, 1999), but straight courses of topographic boundaries of the basin strongly point to the relative subsidence. Basins in the central part of the Sudetes, including the Kladská kotlina Basin and connected troughs to the south and north-west, do not bear any clear evidence for deep weathering. Rock-landform relationships suggest long-term rock-controlled denudation (Placek et al. 2007), superimposed on the more general pattern of uplift and subsidence. The best example of a basin due to subsidence is the Nysa Graben (Ranoszek 1999). One common evolutionary scheme for intramontane basins may simply not exist. The retrospective analysis of Jahn's (1980) paper shows how questionable conclusions can be reached if the transboundary position of the Sudetes is forgotten.

\section{Conclusions}

Geomorphology, as any other science, to maintain its status and scientific nature needs constant updating, critical testing and revisions of previously proposed concepts and models, however well they are embedded in the literature and minds of the geomorphologists. Revisions and re-assessments are usually done after new discoveries have been made, new paradigms have emerged, or new tools supporting research have been made available. This paper has offered an assessment of but one aspect of the geomorphology of the Sudetes, which is the general landform pattern within its geographical limits. The critical re-appraisal of previous concepts has been prompted by two circumstances: one is the increasing availability of digital elevation models and software used to work with them; another one is the strong personal feeling of the author that geomorphological research of the Sudetes can only

2 Granite inselbergs around Žulová, considered as landforms belonging to the tropical generation of Palaeogene age (Demek 1976) are located in the Sudetic Foreland, not in the Sudetes proper. 
advance if the mountains are considered as one entity stretching across the territory of Czechia, Poland, and Germany. Much of the research in the past was sadly restricted to an area on just one side of the border.

The DEM-based analysis of the large-scale geomorphology of the Sudetes allowed for a new look at the old problems as well as for a more objective test of certain concepts introduced in the past. The main conclusions from this exercise are the following:

- The general landform pattern of the Sudetes appears related to differential uplift and subsidence, as assumed by Czech geomorphologists already a few decades ago, however superimposed on a variety of rock - landform relationships arising from variable rock strength and resistance.

- The geomorphological styles of western and eastern part of the Sudetes differ from each other, the primary difference being the abundance of intramontane basins in the former. This may point to more effective Cainozoic extension in the western part, but reasons for this remain obscure.

- The most elevated ( $>1,000 \mathrm{~m}$ a.s.l.) massifs within the Sudetes are associated with the highest mean slope gradients. They are likely to be the loci of surface uplift, within the regional horst-and-graben structure of the Sudetes.

- Neither the model emphasizing the occurrence of tiered levels of relict planation surfaces, nor one assuming the widespread existence of distinctive landforms of tropical morphogenesis find support in the light of region-wide DEM analysis.

- Low-gradient surfaces at high elevation are of very limited extent in the Sudetes. However, they are considerably more widespread at 600-1,000 m a.s.l., particularly in Nízký Jeseník Mts., located in the Carpathians forebulge zone.

- Straight mountain fronts, usually taken as a proxy of active tectonics, are not necessarily associated with high slope gradients. Reasons for this apparent anomaly may reside in mechanical weakness of the footwall and its susceptibility to denudation and erosion, or in relatively low intensity of contemporary uplift.

Acknowledgements: First and foremost, my sincere thanks go to Ms Agnieszka Placek, a co-worker in the research project and co-author of several recent publications, for her substantial intellectual contribution to the renewed interest in the large-scale geomorphology of the Sudetes and for preparation of background maps used in this paper. Comments and advice from Marek Jarosiński and Waldemar Sroka are also gratefully acknowledged, as are helpful suggestions from journal reviewers.

\section{References:}

ADAMS, J. (1985): Large-scale geomorphology of the Southern Alps, New Zealand. In: Morisawa, M., Hack, J. T. (eds): Tectonic Geomorphology. Allen \& Unwin, Boston, pp. 105-128.

ALEKSANDROWSKI, P. (2003): Śródsudecka strefa uskokowa - przykład przesuwczej granicy terranów. In: Ciężkowski, W., Wojewoda, J., Żelaźniewicz, A. (eds): Sudety Zachodnie: od wendu do czwartorzędu. WIND, Wrocław, pp. 105-118.

BADURA, J., PRZYBYLSKI, B. (2005): Application of digital elevation models to geological and geomorphological studies - selected examples. Przegląd Geologiczny, 53, No. 10/2, pp. 977-983. 
BADURA, J., ZUCHIEWICZ, W., GÓRECKI, A., SROKA, W., PRZYBYLSKI, B. (2003): Morfometria strefy sudeckiego uskoku brzeżnego między Złotym Stokiem a Dobromierzem. Przegląd Geologiczny, 51, pp. 1048-1057.

BADURA, J., ZUCHIEWICZ, W., ST?PANČIKOVÁ, P., PRZYBYLSKI, B., KONTNY, B., CACON, S. (2007): The Sudetic Marginal Fault: a young morphotectonic feature at the $\mathrm{NE}$ margin of the Bohemian Massif, Central Europe. Acta Geodynamica et Geomaterialia, 4, No. 4, pp. 7-29.

BALATKA, B., KALVODA J. (2006): Geomorfologické členění reliéfu Čech. Geomorphological regionalization of the relief of Bohemia. Kartografie a.s., Praha, 68 p., 3 maps.

BULL, W. B., McFADDEN, L. D. (1977): Tectonic geomorphology north and south of the Garlock fault, California. In: Doehring, D. O. (ed.): Geomorphology in Arid Regions. Allen and Unwin, London, pp. 115-138.

CHVÁTALOVÁ, A. (2000): Geologické a geomorfologické poměry Lužických hor. Acta Universitatis Purkynianae, 59, Studia Geographica III., PF UJEP, Ústí nad Labem, $79 \mathrm{p}$.

CZUDEK, T. (1977): Reliefgenerationen im Ostteil des Nizky Jesenik (Gesenke) in der Tschechoslovakei. In: Büdel, J. (ed.): Beiträge zur Reliefgenese in verschiedenen Klimazonen. Würzburger Geographische Arbeiten, 45, pp. 39-68.

CZUDEK, T. (1995): Kupovitý reliéf v severní části Nízkého Jeseníku. Časopis Slezského Muzea A, 44, pp. 31-42.

CZUDEK, T., DEMEK, J. (1970): Některé problémy interpretace povrchových tvarů České vysočiny. Zprávy Geografického Ústavu ČSAV, 7, No. 1, pp. 9-28.

CZUDEK, T. et al. (1972): Geomorfologické členění ČSR. Studia Geographica, 23, pp. 1-137.

DEMEK, J. (1975): Planation surfaces and their significance for the morphostructural analysis of the Czech Socialist Republic (ČSR). Studia Geographica, ČSAV, 54, Brno, pp. 133-164.

DEMEK, J. (1976): Pleistocene continental glaciation and its effect on the relief of the northeastern part of the Bohemian Highlands. Studia Societatis Scientiarum Torunensis, C, 8, No. 4-6, pp. 63-74.

DEMEK, J. (1982): Zarovnané povrchy České vysočiny. In: Geomorfologická konference. Karlova univerzita, Praha, pp. 37-46.

DEMEK, J. (2004): Etchplain, rock pediments and morphostructural analysis of the Bohemian Massif (Czech Republic). In: Drbohlav, D., Kalvoda, J., Voženílek, V. (eds): Czech Geography at the Dawn of the Millenium, Czech Geographical Society, Palacky University in Olomouc, Olomouc, pp. 69-81.

GILEWSKA, S. (1991): Rzeźba. In: Starkel, L. (ed.): Geografia Polski. Środowisko przyrodnicze. PWN, Warszawa, pp. 243-288.

IVAN, A. (1990): K charakteru neotektonických pohybů a vývoji reliéfu v oblasti Hrubého Jeseníku a východní části Orlických hor. Casopis Slezského Muzea, A, 39, pp. 277-281.

IVAN, A. (1997): Topography of the Marginal Sudetic Fault in the Rychlebské hory (Mts.) and geomorphological aspects of epiplatform orogenesis in the NE part of the Bohemian Massif. Moravian Geographical. Reports, 5, No. 1, pp. 3-17.

IVAN, A. (1999): Geomorphological aspects of the late Saxonian epiplatform orogeny of the Bohemian Massif (Part 2). Moravian Geographical Reports, 7, No. 2, pp. 12-31.

JAHN, A. (1953): Morfologiczna problematyka Sudetów Zachodnich. Przegląd Geograficzny, 25, pp. 51-59.

JAHN, A. (1980): Main features of the Tertiary relief of the Sudetes Mountains. Geographia Polonica, 43, pp. 5-23.

JAHN, A., CHODAK, T., MIGOŃ, P., AUGUST C. (2000): Utwory zwietrzelinowe Dolnego Śląska. Nowe stanowiska, wiek i znaczenie geomorfologiczne. Acta Universitatis Wratislaviensis, 2238, Studia Geograficzne, 72, 211 p.

KING, L. C. (1953): Canons of landscape evolution. Geological Society of America Bulletin, 64, pp. 721-752.

KLIMÁSZEWSKI, M. (1958): Rozwój terytorium Polski w okresie przedczwartorzędowym. Przegląd Geograficzny, 30, pp. 3-43.

KONDRACKI, J. (1994): Geografia Polski. Mezoregiony fizycznogeograficzne. PWN, Warszawa, $340 \mathrm{~s}$.

KOPECKÝ, A.. (1972): Hlavní rysy neotektoniky Československa. Sborník Geologických Věd, A, No. 6, pp. 77-155.

KOPECKÝ, A. (1986): Neotektonika Hrubého Jeseníku a východní cásti Orlických hor. 
Časopis Slezského Muzea, A, 35, pp. 117-141.

KRZYSZKOWSKI, D., PIJET, E. (1993): Morphological effects of Pleistocene fault activity in the Sowie Mountains, Sudeten, Southwestern Poland. Zeitschrift für Geomorphologie N.F., Supplement-Band, 94, pp. 243-259.

KRZYSZKOWSKI, D., MIGON, P., SROKA, W. (1995): Neotectonic Quaternary history of the Sudetic Marginal Fault. Folia Quaternaria, 66, pp. 73-98.

KUHLEMANN, J., SZEKELY, B., FRISCH, W., DANISIK, M., DUNKL, I., MOLNAR, G., TIMAR, G. (2005): DEM analysis of mountainous relief in a crystalline basement block: Cenozoic relief generations in Corsica (France). Zeitschrift für Geomorphologie, 49, pp. 1-21.

MATMON, A., BIERMAN, P., ENZEL, Y., (2002): Pattern and tempo of great escarpment erosion, Geology, 30, pp. 1135-1138.

MIGON, P. (1991): The origin of stepped topography in the northern part of the Karkonosze granite massif. Bulletin of the Polish Academy of Sciences, Earth Sciences, 39, No. 3, pp. 267-276.

MIGON, P. (1992): Inherited landforms in the crystalline areas of the Sudetes Mts. A case study from the Jelenia Góra Basin, SW Poland. Geographia Polonica, 60, pp. 123-136.

MIGON, P. (1997): Tertiary etchsurfaces in the Sudetes Mountains, SW Poland - a contribution to the pre-Quaternary morphology of Central Europe. In: Widdowson, M. (ed.): Palaeosurfaces: recognition, reconstruction, and palaeoenvironmental interpretation. Geological Society Special Publication, 120, pp. 187-202.

MIGON, P. (1998): Długookresowa ewolucja rzeźby denudacyjnej środkowej i zachodniej Europy. Podstawowe problemy morfogenezy. Acta Universitatis Wratislaviensis, 2080, Studia Geograficzne, 70, 267 p.

MIGOŃ, P. (1999): Residual weathering mantles and their bearing on long-term landscape evolution of the Sudetes. Zeitschrift für Geomorphologie, N. F., Supplement-Band, 119, pp. 71-90.

MIGOŃ, P., PILOUS, V. (2007): Geomorfologie. In: Flousek, J., Hartmanová, O., Štursa, J., Potocki, J. (eds): Krkonoše. Miloš Uhliř - Baset, Praha, pp. 103-124.

MIGOŃ, P., POTOCKI, J. (1996): Rozwój morfotektoniczny centralnej części Gór Izerskich. Acta Universitatis Wratislaviensis, 1808, Prace Instytutu Geograficznego, A8, pp. 69-80.

MILIARESIS, G. (2006): Geomorphometric mapping of Asia Minor from globe digital elevation model. Geografiska Annaler, 88A, pp. 209-222.

PLACEK, A. (2007): Basaltic hills as structural landforms - morphometry versus rock strength (a study from the Kaczawskie upland, SW Poland). Universitatis Ostravensis Acta Facultatis Rerum Naturalium, 237, Geographia-Geologia, No. 10, pp. 111-124.

PLACEK, A., MIGON, P. (2007): Rock-landform relationships in the Sudetes in the light of rock strength assessment using the Schmidt hammer. In: Goudie, A. S., Kalvoda, J. (eds): Geomorphological Variations. Nakladatelství P3K, Prague, pp. 287-311.

PLACEK, A., MIGOŃ, P., ŻYSZKOWSKA, W. (2007): Low-gradient surfaces in the Sudetes - insights from the digital elevation model. Universitatis Ostravensis Acta Facultatis Rerum Naturalium, 237, Geographia-Geologia, No. 10, pp. 94-110.

PRZYBYLSKI, B., BADURA, J. (2004): Czy struktury koliste w Sudetach mogą mieć genezę uderzeniową? Przegląd Geologiczny, 52, pp. 971-978.

RANOSZEK, W. (1999): Zastosowanie różnych metod morfometrycznych w analizie morfologii progu tektonicznego na przykładzie zachodniej krawędzi Masywu Śnieżnika. Przegląd Geologiczny, 47, pp. 1027-1031.

SROKA, W. (1997): Ewolucja morfometryczna Sudetów w rejonie Kotliny Kłodzkiej w świetle analizy morfometryczno-statystycznej. Acta Universitatis Wratislaviensis, 1939, Prace Geologiczno-Mineralogiczne, 58, $97 \mathrm{~s}$.

WALCZAK, W. (1968): Sudety. PWN, Warszawa, 384 s.

WOJEWODA, J. (2007): Neotectonic aspect of the Intrasudetic Shear Zone. Acta Geodynamica et Geomaterialia, 4, No. 4, pp. 31-41.

ŻELAŹNIEWICZ, A. (2005). Przeszłość geologiczna. In: Fabiszewski, J. (ed.): Przyroda Dolnego Śląska. Polska Akademia Nauk - Oddział we Wrocławiu, Wrocław, pp. 61-134. 


\section{HLAVNÍ RYSY GEOMORFOLOGIE SUDET PŘEHODNOCENÉ PODLE DIGITÁLNÍHO ELEVAČNÍHO MODELU}

Sudety jako geomorfologická oblast Českého masivu se vyznačují komplikovaným prostorovým uspořádáním reliéfu o vysoké a nízké nadmořské výšce a různými průměrnými sklony svahů $\mathrm{v}$ celém rozsahu. $\mathrm{V}$ minulosti bylo navrženo několik konceptuálních modelů $\mathrm{k}$ vyhodnocení této rozmanitosti se zdưrazněním významu zarovnaných povrchů a cyklického vývoje reliéfu, mezihorských pánví jako pozůstatků tropické morfogeneze, vzniku tvarů reliéfu následkem klimatu či různých zdvihů a poklesů v neotektonickém období. Lze konstatovat, že v minulosti bylo učiněno jen velice málo pokusů o vytvoření uceleného modelu geomorfologického vývoje Sudet jako celku. Rámce používané českými a polskými gemorfology se liší, což vede k rozdílné interpretaci na pohled podobných tvarů reliéfu.

Cílem této práce je poskytnout nový pohled na formy reliéfu Sudet, zejména za použití výsledků posledních studií digitálního elevačního modelu vytvořeného pro celé Sudety z obou stran státních hranic. Pro polskou stranu Sudet byl vytvořen digitální výškový model (DEM) za pomoci software ArcMap na základě analogových topografických map o měřítku 1:25 000 pomocí ruční vektorizační metody. Byly digitalizovány vrstevnice po $25 \mathrm{~m}$, významné výškové body a všechny vodní toky. Poté byly vektory interpolovány pomocí Topo-to-Raster a byl vytvořen rastr o rozlišení $50 \mathrm{~m}$. Potom byly do modelu pro českou a německou stranu přidány údaje $\mathrm{z}$ digitálních modelů terénu (DTED) o rozlišení $30 \mathrm{~m}$. Zvolené rozlišení a systém geografických souřadnic byly standardizovány a oba modely byly sloučeny. Jako dostačující a vhodné pro následnou analýzu na úrovni regionu bylo zvoleno rozlišení $50 \mathrm{~m}$ a vrstevnice po $25 \mathrm{~m}$. Mapy sklonů byly odvozeny automaticky s využitím postupu Spatial Analyst (Surface Analysis v ArcGIS). Výsledkem tohoto postupu je možnost využití vhodných konceptů dlouhodobého vývoje reliéfu.

Hlavní druhy reliéfu Sudet jsou jasně spojeny s odlišným zdvihem a poklesem, což tvrdili čeští geomorfologové již před několika desítkami let. Analýza digitálního elevačního modelu pro celý region nepodpořila ani zdůrazňování výskytu uspořádaných úrovní reliktních zarovnaných povrchů, ani tvrzení o hojném výskytu zřetelných forem reliéfu tropické morfogeneze. Navíc analýza na základě digitálního elevačního modelu ukazuje, že geomorfologické složení západní a východní části Sudet se navzájem liší, přičemž základním rozdílem je hojnost mezihorských pánví $\mathrm{v}$ západní části. Mohou svědčit o účinnější třetihorní extenzi západní části. Nejvyšší masivy Sudet (přesahující nadmořskou výšku $1000 \mathrm{~m}$ ) vykazují nejvyšší průměrné sklony svahů a jsou pravděpodobně místy výzdvihu povrchu uvnitř regionální hrástové a př́íkopové stavby Sudet. Existuje tedy korelace mezi nadmořskou výškou a stupněm disekce, která odpovídá obecnému pravidlu, že větší výzdvih (jak rozsahem tak stupněm) posiluje erozi, po které následují svahové pohyby, což vede $\mathrm{k}$ vytvoření stálého stavu horské krajiny, která si zachovala jen málo ze své předchozí topografie. Tímto způsobem mohou být vysvětleny všechny části Sudet nad $1200 \mathrm{~m} \mathrm{n}$. m. Naopak mírně svažité povrchy jsou daleko častější v nadmořských výškách 600-1000 m, zejména v Nízkém Jeseníku v předhưr̆í Karpat.

Na závěr je třeba zdůraznit, že tento přístup nemůže plně objasnit původ studovaných forem reliéfu či zjistit jejich stáŕí. Otevírá však nové cesty výzkumu a předkládá pracovní hypotézy k dalšímu ověření. Přesvědčivým způsobem zejména ukazuje, že geomorfologický výzkum Sudet může pokročit pouze tehdy, když tato pohoří budou brána jako jeden celek prostírající se na území Česka, Polska a Německa.

Obr. 1 - Celková hypsometrie Sudet vytvořená z digitálního elevačního modelu. Navržené rozdělení Sudet.

Obr. 2 - Hlavní geologické hranice v Sudetech superponované na digitální elevační model. Tlustá čára označuje hranice mezi západosudetskými a východosudetskými terány (podle Żelaźniewicze 2005), přerušované čáry označují přesahující př́íkrov třetihorních sedimentů. Vysvětleny jsou pouze hlavní geologické jednotky. LM Lužický masiv, KIM - Krkonošsko-jizerský metamorfní masiv, KG - Krkonošskojizerský granitový masiv, NT - Severosudetská brázda, KM - Kaczawská metamorfní jednotka, IT - Vnitrosudetská brázda, SM - masiv Sovích hor, OM - Orlická metamorfní jednotka, UNG - Hornoniská sníženina, LSM - metamorfní jednotka Lądek-Śnieżnik, ESS - Východosudetský sedimentární vrásno-přesmykový pás. 
Obr. 3 - Prostorové rozložení svahů s nízkým sklonem v Sudetech a jejich okolí. Průměrný sklon svahu je počítán pro čtverce o straně $50 \mathrm{~m}$.

Obr. 4 - Prostorové rozložení svahů s vysokým sklonem v Sudetech a jejich okolí. Průměrný sklon svahu je počítán pro čtverce o straně $50 \mathrm{~m}$.

Author is with University of Wroctaw, Department of Geography and Regional Development, pl. Uniwersytecki 1, 50-137 Wroctaw, Poland; e-mail: migon@geogr.uni.wroc.pl.

Arrived to the editorial board on April 18, 2008 